\title{
Conservation of Genetic Diversity in Beans (Phaseolus vulgaris)
}

\author{
Aurel MAXIM ${ }^{1 *}$, Mignon ŞANDOR ${ }^{1}$ Vasile ROMAN ${ }^{1}$, Daniel BONTEA ${ }^{1}$, Adriana OPINCARIU ${ }^{1}$, Lucia \\ MIHALESCU $^{2}$
}
${ }^{1}$ Department of Environmental and Plant Protection, Faculty of Agriculture, University of Agricultural Sciences and Veterinary Medicine Cluj-Napoca
${ }^{2}$ Department of Chemistry-Biology, North University Center at Baia Mare, Tehnical, University of Cluj- Napoca, Victoriei Street, No.76, 430122, Baia Mare, Romania
* corresponding author: aurel.maxim@usamvcluj.ro

Bulletin UASVM series Agriculture 73(2)/2016

Print ISSN 1843-5246; Electronic ISSN 1843-5386

DOI 10.15835/buasvmcn-agr: 12429

\begin{abstract}
In the last two decades, both on International and European level a series of treaties and laws have been devised in order to save local varieties of crop plants. The most important methods of traditional seed conservation are on farm and ex situ (Maxim et al., 2010; Kontoleonet al., 2009). The identification of local Romanian varieties of bean, their morphological and agronomic description, seed production and its spreading in the purpose of genetic erosion reduction. Their have been taken into study 13 local varieties of bean. For the morphological description descriptors have been used accordingly to the IPGRI (International Plant Genetic Resources Institute). For the evaluation of the diseases attack, frequency (F\%), intensity (I\%) and degree of attack (GA\%) have been calculated.The exchanges of seed between farmers were facilitated through the online catalog edited by the Eco Ruralis Association that promotes traditional seeds. Of the 13 local varieties of beean taken into study, two are with determined growth(15.3\%), and 11 are with undetermined growth(84.7\%). The most significant production of pods on the plant was documented on local variety MM 1039 (2.736 kg), and the most significant production of beans on plant was documented on local variety HD 904 (1.156kg). The most resistant varieties against bacterian attack, anthracnose, aphids and rust were: SJ 890, CJ 909, CV 917 şi HD 1159. The growing phenomenon of genetic erosion implies the indentification and the conservation of crop plants. In the year 2015, 13 local varieties of bean have been taken into study that were used for conservation in seeds' genbank and for the exchange of seeds between farmers.
\end{abstract}

Keywords: agrobiodiversity, bean, bioconservation, landraces, "on farm".

\section{INTRODUCTION}

In the last two decades, the last two decades, both at international and European level a series of treaties and directives were created in order to save the local varieties of crop plants. The main cause of genetic erosion in crop plants is the practice of agricultural industrialized systems based upon intensive use of chemicals, the use of mechanical tehnologies and modern varieties of crops, very alike.

Local varieties of crop plants present a series of advantages both in the medium and long term.
These can hold adaptive genes to biotic and abiotic stress factors, given that they may come from a very harsh pedoclimatic enviroment (Veteläinen et al., 2009). FAO (2008) encourages the conservation of local crop varieties, arguing that only rich genetic resources will be able to insure the efficient use of water and nutrients resources but also heat tolerance, in the context of global warming.

The most important methods of traditional seeds conservation is on farm and ex situ (Maxim et al., 2010; Kontoleon et al., 2009).

The Genetic Vegetal Resources Bank Suceava 
holds a number of 56 varieties of beans (10). From the genetic diversity in beans' point of view, the best represented areas are Maramures, followed by Suceava and Apuseni Mountains (Străjeru et al., 2009). In Bulgaria a similar institution (Bulgarian National Institute of Plant Genetic Resources) holds 1452 accesions of beans (Krasteva et al., 2009).

\section{MATERIALS AND METHODS}

They were taken into study 13 local varieties of beans from 10 counties of Transylvania, as follows: CV 917, MS 914, MS 1132, SJ 890, MM 1039, CJ 921, SM 906, BH 905, HR 907, CJ 909, BN 902, HD 904 and HD 1159. Every variety received a code wich has two components:

First is the abreviation of the county from where the genetic material originates, and the number represents the order in wich the local variety was registred in the data base

The crop technology was specific to the ecological crop system. No plant treatments were used, in order to make possible a precise evaluation of the genetic ressistance of the plant varieties towards the parasites attacks. In the experimental field no chemical or organic fertilisers were applied.

The bean seeds were seeded on the 28th of May 2015 in nests of 20-25 seeds. In the vegetation period poles were installed for the 11 local varieties of beans with undetermined growth and also measurements, descriptions and pictures were taken for every local variety. The descriptions were made accordingly with the IPGRI (International Plant Genetic Resources Institute) recommended descriptors and they were focused mainly on the followings: growth type, colour of the flowers, size of the leaves and pods, average weight of the bean, average number of beans and the production of beans per nests, average weight and colour of the riped beans, production of beans per plant nest, earliness etc.

Observations were made regarding the attack of the following pests and diseases: common beans burning (Xanthomonas phaseoli), anthracnose (Colletotrichum lindemuthianum), rust (Uromyces appedinculatus) and aphids.

The diseases attack was value represented through frequency (F\%), intensity (I\%) and degree of attack (GA\%).

The frequency of the attack is a relative value of the plants number or plants attacked organs (n) relative to the number of plants or observed organs $(\mathrm{N})$. The frequency values was achieved through direct observations of a number of plants or organs, depending on cases and conditions. There are different methods of sample collection or on how to make observations. Following the observations, the raw data was generated through the following relation: $\mathrm{F} \%=\mathrm{n} \times 100 / \mathrm{N}$.

The intensity of the attack is a relative value through wich the coverage degree or extension of the attack on plant, obtained by dividing the attacked surface at the total observed surface. As criteria for intensity expresion scales are used that can have a different classes of grading (with 4-5-6-10 classes). In our research the scale wih 6 classes of attack was used, responsible for specific procentage intervals of the intensity of the attack, as it follows: $1-3 \%$ attacked surface - score 1; 4-10\% attacked surface - score 2; 11$25 \%$ attacked surface - score 3; 26-50\% attacked surface - score 4; 51-75\% attacked surface - score 5; 76-100\% attacked surface - score 6;

The relative expression of the attack is given by the relation:

$$
\mathrm{I}=\Sigma(\mathrm{i} \times \mathrm{f}) / \mathrm{n}
$$

where: $\mathrm{i}=$ the score or the procentage of attack coverage

$\mathrm{f}=$ number of cases with attack at every score

$\mathrm{n}=$ total number of attack cases

At aphids, the recorded data attack was borderd in different categories: no attack, small, medium, strong, very strong.

The obtained seeds were used for conservation in the seed bank and for the exchange of seeds between farmers.

\section{RESULTS AND DISCUSSION}

The data from tabel 1 shows that in the year 2015, in the experimental field, local varieties CV 917, MS 914, MS 1132, SJ 890, MM 1039, CJ 921, SM 906, BH 905, ER 907, CJ 909, ER 90 have a undetermined growth and BN 902 and HD 1159 have a determined growth. The dimension of the leaves vary between $8 \times 4 \mathrm{~cm}$, at MS 914, HD 904, HD 1159 and $13 \times 9$ at SJ 890.

The colour of the leaves is very diverse. Therefore, local varieties CJ 921 and SM 906 have white flowers; MS 1132 - yellowish white, CV 917 - 


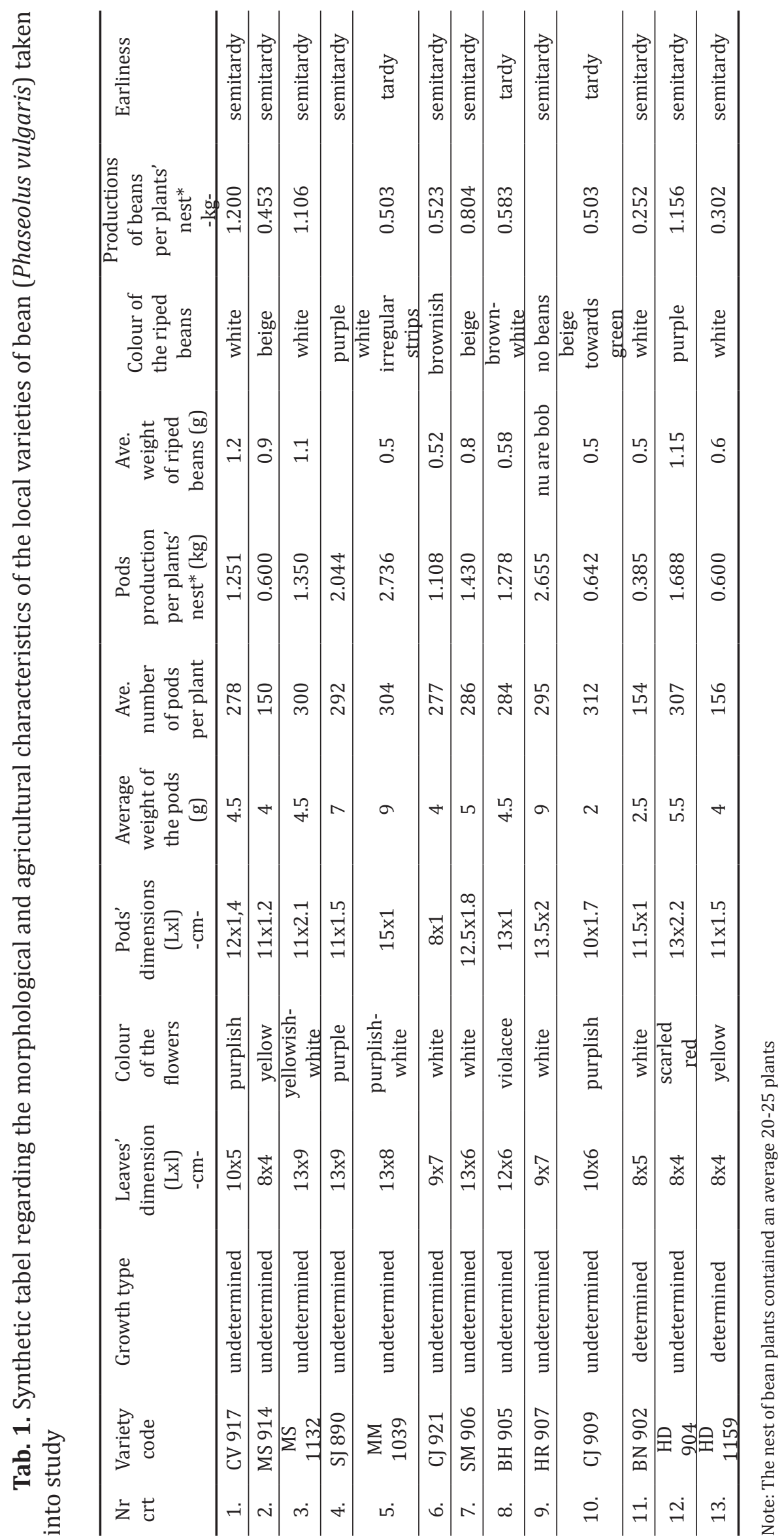


Tab.2. The behaviour of different local varieties of bean (Phaseolus vulgaris) towards diseases and pests

\begin{tabular}{|c|c|c|c|c|c|c|c|}
\hline \multirow[t]{2}{*}{$\begin{array}{l}\text { Nr. } \\
\text { crt. }\end{array}$} & \multirow[t]{2}{*}{ Variety cod } & \multicolumn{2}{|c|}{$\begin{array}{c}\text { Xanthomonas phaseoli } \\
\text { GA (\%) }\end{array}$} & \multicolumn{2}{|c|}{$\begin{array}{c}\text { Colletotrichum } \\
\text { lindemuthianum } \\
\text { GA (\%) }\end{array}$} & \multirow{2}{*}{$\begin{array}{c}\text { Uromyces } \\
\text { appedinculatusGA } \\
(\%) \\
\text { leaves }\end{array}$} & \multirow{2}{*}{$\begin{array}{c}\begin{array}{c}\text { Aphids } \\
\text { - atac - }\end{array} \\
\text { small }\end{array}$} \\
\hline & & leaves & pods & leaves & pods & & \\
\hline 1. & CV 917 & 0 & 0 & sporadic & 0 & sporadic & 0 \\
\hline 2. & MS 914 & 1.1 & 0.3 & 0.52 & 0.36 & 0.24 & large \\
\hline 3. & MS 1132 & sporadic & 0 & 0.5 & sporadic & 0 & sporadic \\
\hline 4. & SJ 890 & 0 & 0 & sporadic & 0 & sporadic & 0 \\
\hline 5. & MM 1039 & 0.3 & 0.24 & 0 & 0 & 0.39 & 0 \\
\hline 6. & CJ 921 & 0.45 & sporadic & 0 & 0 & 0 & sporadic \\
\hline 7. & SM 906 & 0 & 0 & 0.72 & sporadic & 0 & 0 \\
\hline 8. & BH 905 & 0 & 0 & 0.24 & 0.15 & 1.68 & medium \\
\hline 9. & HR 907 & 1.26 & 0.39 & 0.3 & sporadic & 0.51 & small \\
\hline 10. & CJ 909 & sporadic & 0 & sporadic & 0 & sporadic & sporadic \\
\hline 11. & BN 902 & 1.33 & 3.2 & 0.3 & sporadic & 0 & medium \\
\hline 12. & HD 904 & 0.96 & 0.45 & sporadic & 0 & sporadic & small \\
\hline 13. & HD 1159 & sporadic & 0 & sporadic & 0 & 0 & 0 \\
\hline
\end{tabular}

purple, MM 1039 -purplish white, HD 904 - scarlet red, MS 914 and HD 1159 - yellow.

The dimension of the pods also varies, the longest average length of the pods is recorded on $(13.5 \mathrm{~cm})$ and the weidest pods were registered on HD $904(2.2 \mathrm{~cm})$.

The average beans per nest of plants was under $1 \mathrm{~kg}$ on MS 914, CJ 909, BN 902 ȘI HD 1159. Only three local varieties registered productions over 2 kg: SJ 890 (2.044 kg), MM 1039 (2.736) and HR 907(2.655 kg). All other local varieties had productions situated between 1-2 kg per nest of plants.

The average weight of riped beans was between $0.5 \mathrm{~g}$ (MM 1039, CJ 909, ER 902) and 1.15 g (HD 904).

The colour of the beans is very diverse, as follows: CV 917 - white, MS 914 - beige, SJ 890 purple, CJ 921 - brownish, CJ 909 - beige towards green, BH 905 - brown with white.

The production of beans per nest of plants (kg), in descending order is the following: CV 917 - 1.200; HD 904 - 1.156; MS 1132 - 1.106; SM 906 - 0.804; BH 905 - 0.583; CJ 921 - 0.523; CJ 909 0.503; MM 1039 - 0.503; MS 914 - 0.453; HD 1159 - 0.302; BN $902-0.252$.

Among the 13 local varieties of beans taken into study most are semitardy (CV 917, MS 914, MS 1132, SJ 890, CJ 921, SM 906, HR 907, BN 902,
HD 904, HD 1159), and three of wich are tardy (MM 1039, BH 905, CJ 909).

The largest attack of common burn of the bean (Xanthomona sphaseoli) was recorded on the local variety BN 902 (GA $=1.33 \%$ on leaves and $3.2 \%$ on pods), while, CV 917, SJ 890, SM 906, BH 905 proved to be the most resistant. The most sensible variety of bean towards anthracnose (Colletotrichum lindemuthianum) is SM 906, with $0.72 \mathrm{GA} \%$ on leaves and sporadic on pods. MM 1039 and CJ 921 had no attack on leaves nor on the pods. The most resistant local varieties of beans towards rust were MM 1132, CJ 921, SM 906, BN 902, HD 1159, and towards aphids, CV 917, SJ 890, MM 1039, SM 906, HD 1159 (Tabel 2).

In general, the most resistant conservation varieties against studied parasites were: SJ 890, CJ 909, CV 917 şi HD 1159.

No signs of other diseases or pests were recorded.

Similar studies as ours were conducted on beans from the area Sierra Norte of Madrid by the Lazaro et al (2013). The authors studied the agro-morphological characterization, but also the production, of 46 local varieties and comercial type. Durán et al (2005) studied 65 local varieties of bean from Caraibe, and Chacón (2005) researched 165 local varieties of bean, but also 134 wild varieties from Latin America and USA. Different from the 
mentioned authors, we dedicaded increased attention towards the resistance of the local varieties against diseases and pests - essential element for durabile agricultural practice.

\section{CONCLUSION}

1. Their have been taken into study 13 local varieties of bean. For the morphological description descriptors have been used accordingly to the IPGRI (International Plant Genetic Resources Institute).

2. For the evaluation of the diseases attack, frequency $(\mathrm{F} \%)$, intensity $(\mathrm{I} \%)$ and degree of attack (GA\%) have been calculated.

3 . The exchanges of seed between farmers were facilitated through the online catalog edited by the Eco Ruralis Association that promotes traditional seeds.

4. Of the 13 local varieties of beean taken into study, two are with determined growth $(15.3 \%)$, and 11 are with undetermined growth (84.7\%). The most significant production of pods on the plant was documented on local variety MM 1039 $(2.736 \mathrm{~kg})$, and the most significant production of beans on plant was documented on local variety HD 904 (1.156 kg). The most resistant varieties against bacterian attack, anthracnose, aphids and rust were: SJ 890, CJ 909, CV 917 şi HD 1159.

5 . The growing phenomenon of genetic erosion implies the indentification and the conservation of crop plants. In the year 2015, 13 local varieties of bean have been taken into study that were used for conservation in seeds' genbank and for the exchange of seeds between farmers.

\section{REFERENCES}

1. Chacón S, Pickersgill MI, Debouck B (2005). Domestication patterns in common bean (Phaseolus vulgaris L.) and the origin of the Mesoamerican and Andean cultivated races. Theoretical and Applied Genetics, 110(3):432-444.

2. Durán LA, Blair MW, Giraldo MC, Macchiavelli R, Prophete E, Nin JC, and Beaver JS (2005). Morphological and Molecular Characterization of Common Bean Landraces and Cultivars from the Caribbean. Crop Sci. 45:1320-1328.

3. Kontoleon, A., Pascual, U and Smale, M. (2009). Agrobiodiversity conservation and economic development, 2009. MPG Books Ltd, Bodmin, Great Britain.

4. Krasteva L, Stoilova T, Varbanova K, Neykov S (2009). Bulgarian Landrace Inventory - Significance and use. European Strategic Approach to Conserving Crop Landraces. Biodiversity Technical Bulletin no 15. European Cooperative Programme for Plant Genetic Resources. Rome, Italy.

5. Lázaro A, Villar B, Aceituno-Mata L, Tardío L, De la Rosa L (2006). The Sierra Norte of Madrid: an agrobiodiversity refuge for common bean landraces. Genetic Resources and Crop Evolution, 60(5):1641-1654.

6. Maxim A (2010). Agrobiodiversitate și bioconservare. Editura Risoprint, Cluj-Napoca.

7. Străjeru S, Ibanescu M, Constantinovici (2009). Landrace Inventories: Nees and Methodologies. Biodiversity Technical Bulletin no 15. European Cooperative Programme for Plant Genetic Resources. Rome, Italy.

8. Veteläinen, M., Negri, V., Maxted, N. (2009). A European Strategic Approach to Conserving Crop Landraces. Biodiversity Technical Bulletin no 15. European Cooperative Programme for Plant Genetic Resources. Rome, Italy.

9. *** FAO (2008). Climate Change and Biodiversity for Food and Agriculture. Technical Background Document from the Expert Consultation Held on 13 to 14 February, 2008.

10. ${ }^{* * *}$, http://www.svgenebank.ro/svgbstatistics1_ ro.asp 